Abstracted/indexed in Academic Search Complete, Agroforestry Abstracts, Asia Journals Online, Bangladesh Journals Online, Biological Abstracts, BIOSIS Previews, CAB Abstracts, Current Abstracts, Directory of Open Access Journals, EMBASE/Excerpta Medica, Google Scholar, HINARI (WHO), International Pharmaceutical Abstracts, Open J-gate, Science Citation Index Expanded, SCOPUS and Social Sciences Citation Index

\title{
Oxidative metabolic changes in pleural fluid of tuberculosis
} \section{patients}

\author{
Y. Narsimha Reddy, S. Vasudeva Murthy, D. R. Krishna and M. C. Prabhakar \\ Department of Pharmacology, University College of Pharmaceutical Sciences, Kakatiya University, Wa- \\ rangal 506009 , India.
}

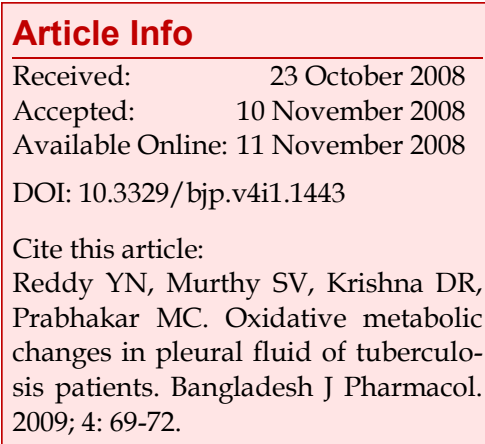

\begin{abstract}
The pleural fluid was aspirated from the tuberculous patients both untreated and under treatment with three months anti-tuberculosis therapy. The amount of malondialdehyde, lactate dehydrogenase, and total protein content in pleural fluid of untreated tuberculous patients were found to be significantly higher when compared with under treatment group. The pleural fluid total anti-oxidant levels were significantly lower in untreated cases in comparison to under treatment. Decrease in the total anti-oxidant status was more pronounced in untreated cases, established that anti-oxidants were nearly completely utilized to scavenge the free radicals. Our findings further support the importance of anti-oxidants in the treatment of tuberculous patient.
\end{abstract}

\section{Introduction}

Mycobacterium can induce reactive oxygen species production by activating phagocytes (May and Spagnuolo, 1987; Attwood et al., 1996) and although an important part of the host defense against mycobacteria, enhanced reactive oxygen species generation may promote tissue injury and inflammation. This further contributes to immunosuppression (Jack et al., 1994; Grimble, 1994). Moreover the malnutrition that commonly occurred in patients with tuberculosis may further contribute to the impaired anti-oxidant capacity in these patients. Severe oxidative stress has been reported in tuberculosis patients because of malnutrition and poor immunity (Reddy et al., 2004). The prospective study was under taken to evaluate the role of oxidative stress in pleural fluid of tuberculosis patients.

\section{Materials and Methods}

The research protocol was approved by the ethical committee constituted by University College of Pharmaceutical Sciences, Kakatiya University,
Warangal, India and patients consent was taken prior to the study. The subjects for this study comprised of $\mathrm{TB}$ patients including untreated $\left(\mathrm{TB}_{1}\right)$, under treatment $\left(\mathrm{TB}_{2}\right)$. TB patients participated in this study were from Government Chest Diseases and TB Hospital, Warangal, Andhra Pradesh. Initial evaluation of a patient with effusion consists of history, physical examination, laboratory investigations and roentgenographic studies. Prior to aspiration analgesic or sedative (I.V. midazolam) was administered if patient shows excessive anxiety. $1 \%$ xylocaine was infiltrated intradermally, subcutaneously and into muscles and parietal pleura and continued till the fluid is aspirated. A 20 or 22 gauge needle is passed along the line of anesthesia, while aspirating $30 \mathrm{~mL}$ of fluid.

The amount of lipid peroxidation products present in the pleural fluid was estimated by the thiobarbituric acid reactive substances (TBARS) method (Carbonneau et al., 1991), which measures the malondialdehyde reactive products by using high performance liquid chromatography (HPLC, Shimadzu LC-8A solvent delivery module, SPD-10AVP UV-Visible spectrophotometer detector, Class CR-10 data processor). Using Altec $\mathrm{C}_{18}$ column $(25 \mathrm{~cm}$ length, 4.6 
mm diameter, $5 \mu \mathrm{m}$ size) and developed with a mobile phase of methanol: water (70: 100) containing $550 \mathrm{~mL}$ of $\mathrm{H}_{3} \mathrm{PO}_{4}$ with $80 \mathrm{nM}$ of $\mathrm{NaOH}$ and $20 \mathrm{~mL}$ sample was injected.

Catalase measurement was done based on the ability of catalase to oxidize hydrogen peroxide (Beers and Sizer, 1952). The change in absorbance was measured for was measured at $240 \mathrm{~nm}$ for $3 \mathrm{~min}$. The results were expressed in terms of $\mathrm{IU} / \mathrm{mL}$ of pleural fluid. For the estimation of total anti-oxidant status, we used a stable free radical $\alpha, \alpha$-diphenyl- $\beta$-picryl hydrazyl (DPPH), at the concentration of $0.2 \mathrm{mM}$ in methanol (Blios, 1958; Kalpana et al., 2001), ascorbic acid was used as a reference standard. The standard graph was plotted using different concentrations of ascorbic acid and the anti-oxidant status values were expressed in terms of $\mathrm{nM}$ of ascorbic acid. Lactate dehydrogenase is zinc containing intracellular enzyme concerned with reversible oxidation of pyruvate to lactate, involves in glycolytic cycle. The reaction velocity is determined by a decrease in absorbance at $340 \mathrm{~nm}$ resulting from oxidation of NADH (Varley et al., 1980). Pleural fluid total protein content was estimated by the method of Lowry et al., 1951. Proteins form chromophoric complex with phenol reagent, which was measured at 610 nm using UV-VIS spectrophotometer (Elico, SL-150). The protein content was calculated from standard curve prepared with bovine serum albumin and expressed in terms of $\mathrm{g} \%$. Statistical evaluation was done using student t-test.

\section{Results}

Lipid peroxidation product and malondialdehyde level estimated in the pleural fluid of tuberculous patients (Table I) was significantly decreased $(p<0.001)$ in under treated cases when compared with untreated cases. The levels were decreased with clinical improvement with anti-tuberculosis therapy. The pleural fluid lipid peroxide levels were found to be significantly high $(p<0.001)$ in untreated cases in comparison with under treated cases of all three categories used different treatment regimens, the lipid peroxidation levels were more in category 2.

In the present study catalase level in pleural fluid of the both untreated and under treated cases it was found that the difference was not statistically significant and the catalase level was low even after completion of antituberculosis therapy. The anti-oxidant levels were increased significantly $(\mathrm{p}<0.01)$ in under treated cases in comparison with untreated cases. The pleural fluid anti-oxidant status in under treatment patients with different treatment regimen, in category 1 and 3 was significantly increased $(\mathrm{p}<0.01)$ in comparison with untreated patients, there was no significant variation in category 2 (Table II). Lactate dehydrogenase level was decreased significantly $(p<0.01)$ in under treated cases in comparison with untreated cases. In tuberculous patients based on treatment regimen, the pleural fluid lactate dehydrogenase levels were decreased significantly $(\mathrm{p}<0.01)$ in all the under treated cases in comparison with untreated cases. The total protein content of pleural fluid was decreased in under treated cases in comparison with untreated cases. There was no significant $(p>0.05)$ variation in the levels of lipid peroxide, catalase, lactate dehydrogenase, total protein found among all the categories receiving different dosage regimen.

\section{Discussion}

In this study, we have demonstrated oxidative stress in the pleural fluid at different stages i.e. before treatment (untreated) and under treatment in tuberculous patients with anti-tuberculosis therapy. Reactive oxygen species generated as a result of ischemic-reperfusion associated with hemorrhage has been proposed to contribute to the progress of acute lung injury (Sen and Packer, 1996). Superoxide is one of the ROS that mediate lung injury (Chan and Goldkorn, 2000). Our finding documents the oxidative stress in tuberculosis patients as the pleural fluid lipid peroxidation product, malondialdehyde level was significantly increased in untreated cases when compared with under treated cases, the malondialdehyde level was gradually decreased with anti-tuberculosis therapy.

\begin{tabular}{|c|c|c|c|}
\hline \multicolumn{4}{|c|}{ Table I } \\
\hline \multicolumn{4}{|c|}{$\begin{array}{l}\text { Levels of malondialdehyde, catalase, total anti-oxidant status, lactate dehydrogenase and total protein leve } \\
\text { in pleural fluid untreated and under treated patients of tuberculosis }\end{array}$} \\
\hline Parameters & Untreated group & Under treated group & $\mathrm{p}$ value \\
\hline Malondialdehyde (nM/mL) & $6.4 \pm 1.4$ & $4.9 \pm 0.8$ & $<0.001$ \\
\hline Catalase (IU/mL) & $43.9 \pm 4.7$ & $44.3 \pm 6.8$ & ns \\
\hline Total anti-oxidant status $(\mathrm{nM} / \mathrm{mL})$ & $44.3 \pm 7.3$ & $53.8 \pm 7.5$ & $<0.01$ \\
\hline Lactate dehydrogenase (IU/L) & $148.7 \pm 23.8$ & $132.2 \pm 13.2$ & $<0.01$ \\
\hline Total protein content $(\mathrm{g} \%)$ & $3.3 \pm 0.6$ & $2.6 \pm 0.3$ & $<0.01$ \\
\hline
\end{tabular}


Table II

\begin{tabular}{|c|c|c|c|c|}
\hline Parameters & & Category 1 & Category 2 & Category 3 \\
\hline \multirow{3}{*}{ Malondialdehyde (nM/mL) } & & $\mathrm{n}=7$ (in each group) & $\mathrm{n}=6$ (in each group) & $\mathrm{n}=6$ (in each group) \\
\hline & $\mathrm{TB}_{1}$ & $6.1 \pm 0.9$ & $8.2 \pm 1.1$ & $6.1 \pm 0.7$ \\
\hline & $\mathrm{TB}_{2}$ & $4.2 \pm 0.7$ & $5.1 \pm 0.8$ & $4.8 \pm 0.3$ \\
\hline \multirow{3}{*}{ Catalase $(\mathrm{IU} / \mathrm{mL})$} & & $\mathrm{p}<0.001$ & $\mathrm{p}<0.001$ & $\mathrm{p}<0.01$ \\
\hline & $\mathrm{TB}_{1}$ & $43.4 \pm 3.2$ & $41.7 \pm 6.2$ & $47.0 \pm 3.3$ \\
\hline & $\mathrm{TB}_{2}$ & $46.0 \pm 8.1$ & $40.5 \pm 5.7$ & $46.6 \pm 3.2$ \\
\hline \multirow{4}{*}{ Total anti-oxidant status (nM/mL) } & & ns & ns & ns \\
\hline & $\mathrm{TB}_{1}$ & $43.5 \pm 5.3$ & $45.0 \pm 7.5$ & $41.8 \pm 6.0$ \\
\hline & $\mathrm{TB}_{2}$ & $55.4 \pm 6.6$ & $47.0 \pm 4.5$ & $59.0 \pm 6.2$ \\
\hline & & $\mathrm{p}<0.01$ & ns & $\mathrm{p}<0.01$ \\
\hline \multirow[t]{2}{*}{ Lactate dehydrogenase (IU/L) } & $\mathrm{TB}_{1}$ & $157.4 \pm 20.5$ & $166.2 \pm 9.7$ & $179.6 \pm 16.2$ \\
\hline & $\mathrm{TB}_{2}$ & $126.5 \pm 13.6$ & $143.0 \pm 4.2$ & $121.0 \pm 12.4$ \\
\hline \multirow{4}{*}{ Total protein levels (g \%) } & & $\mathrm{p}<0.01$ & $\mathrm{p}<0.001$ & $\mathrm{p}<0.001$ \\
\hline & $\mathrm{TB}_{1}$ & $3.0 \pm 0.6$ & $3.6 \pm 0.7$ & $3.2 \pm 0.4$ \\
\hline & $\mathrm{TB}_{2}$ & $2.6 \pm 0.3$ & $2.3 \pm 0.4$ & $2.6 \pm 0.3$ \\
\hline & & ns & $\mathrm{p}<0.01$ & $\mathrm{p}<0.01$ \\
\hline \multicolumn{5}{|c|}{$\begin{array}{l}\text { Data are mean } \pm \mathrm{SD} ; \mathrm{ns}=\text { Not significant; } \mathrm{TB} 1=\text { Untreated; } \mathrm{TB} 2=\text { Under treatment; Category } 1 \text { : Isoniazid }(\mathrm{H})+\text { Ethambutol }(\mathrm{E})+\mathrm{Rifampicin}(\mathrm{R} \\
+ \text { Pyrazinamide }(\mathrm{Z}) \text { daily for } 2 \text { months; followed by } \mathrm{H} \text { and } \mathrm{R} \text { for } 4 \text { months }(2 \mathrm{EHRZ}+4 \mathrm{RH}) \text {; Category } 2: \text { Streptomycin }(\mathrm{S})+\mathrm{H}+\mathrm{R}+\mathrm{Z}+\mathrm{E} \text { dail } \\
\text { for } 3 \text { months; followed by } \mathrm{E}+\mathrm{H}+\mathrm{R}+\mathrm{Z} \text { for } 2 \text { months; followed by } \mathrm{R}+\mathrm{H}+\mathrm{E} \text { daily for } 6 \text { months }(3 \mathrm{SHRZZ}+2 \mathrm{EHRZ}+6 \mathrm{RHE}) ; \text { Category } 3: \mathrm{R} \\
\mathrm{H}+\mathrm{E} \text { daily for } 2 \text { months, followed by } \mathrm{R}+\mathrm{H} \text { for } 4 \text { months }(2 \mathrm{RHE}+4 \mathrm{RH})\end{array}$} \\
\hline
\end{tabular}

In present investigation both untreated and $\mathrm{TB}_{2}$ patients showed that there was no significant variation in estimated catalase (anti-oxidant enzyme) levels in pleural fluid. And our results suggest that antituberculosis therapy not induced any biochemical changes in catalase level.

Previous papers illustrated that reduced concentrations of vitamin A, C and E in patients with tuberculosis (Plit et al., 1998; Rwangabwoba et al., 1998; Dubey et al., 1985). Several factors such as low food intake, nutrient malabsorption, insufficient nutrient release from the liver, acute phase response and an inadequate availability of carrier molecules may influence circulating anti-oxidant concentrations (Rock et al., 1996; Siez and Stahl, 1995; Das et al., 1996). Low vitamin $C$ intake may increase the susceptibility to various infections and lower vitamin $C$ concentration in plasma was associated with substantially higher incidence of tuberculosis (Awotedu et al., 1984). Our present results shows the total anti-oxidant status in the pleural fluid of untreated patients was significantly decreased in comparison with under treatment, indicating that there was an oxidative stress in pleural fluid of tuberculous patients, may lead to increased levels of reactive oxygen species, which may be responsible for pulmonary damage and lung fibrosis.

Tuberculosis is the chronic infectious disease affecting many organs. Organ injury results in the release of lactate dehydrogenase into blood; elevated serum level of lactate dehydrogenase is a useful indicator of organ injury (La Due et al., 1954). In the present study, estimated lactate dehydrogenase levels were high in untreated cases when compared with under treatment cases, the levels were gradually decreased with clinical improvement with anti-tuberculosis therapy. The results were indicating that there was a continuous pulmonary damage due to the release of lactate dehydrogenase and reactive oxygen species .

In the present findings it was demonstrated that the total protein content of pleural fluid was significantly high in untreated tuberculous patients, when compared with under treatment, the protein level was decreased with therapeutic improvement under anti-tuberculosis therapy. The increased levels of total proteins in pleural fluid of tuberculous patients could be the reason for damage of lungs by superoxide, one of the reactive oxygen species that mediate lung injury (Chan and Goldkorn, 2000). Another factor may be the leakage of lactate dehydrogenase from cell membranes into the pleural fluid indicates that there is a definite amount of cellular damage that could be mediated through free radicals (Murray et al., 1990).

These findings further support a link between oxidative stress and tuberculosis. Nutrition supplementation may 
signify a novel approach for fast recuperation. Hence for the therapeutic benefit of the exogenously administered anti-oxidants like vitamin $\mathrm{C}$, tocopherols etc are to be assessed under carefully controlled clinical system.

\section{Acknowledgements}

The authors are thankful to all staff members of the Government Chest \& TB Hospital, Warangal for their kind help in providing the pleural fluid samples during this study.

\section{References}

Attwood EM, Weich DJ, Oosthuizen JM. The influence of carbon particles on the concentration of acid phosphatase and lysozyme enzymes within alveolar macrophages during the killing degradation of Mycobacterium bovis. Tuber Lung Dis. 1996; 77: 341-47.

Awotedu AA, Sofowara EO, Ette SI. Ascorbic acid deficiency in pulmonary tuberculosis. East Afr Med J. 1984; 61: 283-87.

Beers RF, Sizer IW. A spectrophotometric method for measuring the breakdown of hydrogen peroxide by catalase. J Biol Chem. 1952; 195: 133-40.

Blios MS. Anti-oxidant determination by the use of stable free radical. Nature 1958; 26: 1199-202.

Carbonneau MA, Peuchant E, Sess D. Free and bound malondialdehyde measured as thiobarbituric acid abduct by HPLC in serum and plasma. Clin Chem. 1991; 37: 1423-29.

Chan C, Goldkorn T. Ceramide path in human lung cell death. Am J Respir Cell Mol Biol. 2000; 22: 460-68.

Das BS, Thurnham DI, Das DB. Plasma $\alpha$-tocopherol, retinol and carotenoids in children with falciparum malaria. Am J Clin Nutr. 1996; 64: 94-100.

Dubey SS, Sinha KK, Gupta JP. Vitamin C status, glutathione and histamine in gastric carcinoma, tuberculous enteritis and non-specific ulcerative colitis. Indian J Physiol Pharmacol. 1985; 29: 111-14.

Grimble RF. Malnutrition and the immune response. Trans Soc Trop Med Hyg. 1994; 88: 615-19.

Jack CI, Jackson MJ, Hind CR. Circulating markers of free radical activity in patients with pulmonary tuberculosis. Tuber Lung Dis. 1994; 75: 132-37.

Kalpana T, Karunakar N, Reddy MS, Prabhakar MC, Krishna DR. Assessment of anti-oxidant activity of some antileprotic drugs. Drug Res. 2001; 51: 633-37.

La Due JS, Wroblewski F, Karmen A. Serum glutamic oxaloacetic transaminase activity in human acute myocardial infarction. Science 1954; 120: 497-500.

Lowry OH, Rosenbough NJ, Farr Randall RJ. Protein measurement with folin phenol reagent. J Bio Chem. 1951; 193: 165.

May ME, Spagnuolo PJ. Evidence for activation of a respiratory burst in the interaction of human neutrophils with Mycobacterium tuberculosis. Infect Immun. 1987; 55: 2304-07.

Murray KR, Granner DK, Mayes PA, Rodweld VW. Chemical constituents of blood and body fluids. Harper's Biochemistry. 2nd ed. USA, Lange Medical Book, 1990, pp 685-90.

Plit ML, Theron AJ, Fickl H, Van Rensburg CE, Pendel S, Anderson R. Influence of anti-microbial chemotherapy and smoking status on the plasma concentrations of vitamin C, vitamin $\mathrm{E}$, beta carotene, acute phase reactants, iron and lipid peroxides in patients with pulmonary tuberculosis. Int J Tuberc Lung Dis. 1998; 2: 590-96.

Reddy YN, Murthy SV, Krishna DR, Prabhakar MC. Role of free radicals and anti-oxidants in tuberculosis patients. Indian J Tuberc. 2004; 51: 213-18.

Rock CL, Jacob RA, Bowen PE. Update on the biological characteristics of the anti-oxidant micronutrients: Vitamin C, vitamin E and carotenoids. J Am Diet Assoc. 1996; 96: 693 -704 .

Rwangabwoba JM, Fischman H, Semba RD. Serum vitamin A levels during tuberculosis and immunodeficiency virus infection. Int J Tuberc Lung Dis. 1998; 2: 771-73.

Sen CK, Packer L. Anti-oxidant and redox regulation of gene transcription. FASEB J. 1996; 10: 709-20.

Siez H, Stahl W. Vitamin E and C, $\beta$-carotene and other carotenoids as anti-oxidants. Am J Clin Nutr. 1995; 62: 131521.

Varley H, Gowenlock AH, Bell M. Determination of serum lactate dehydrogenase activity. In: Clinical biochemistry. $5^{\text {th }}$ ed. London, Williams Hieinemann Medical Books Ltd, 1980, pp 715-20.

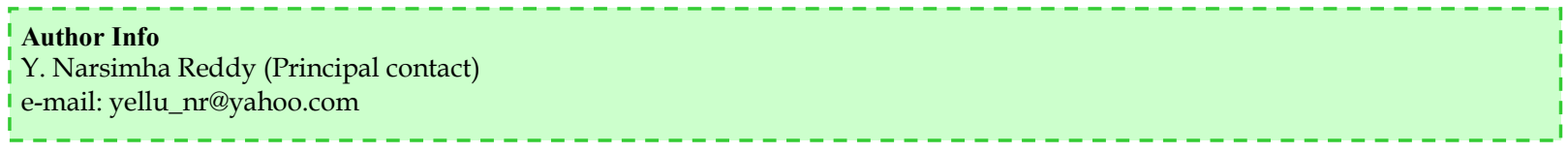

